Interactive comment on "Modification, Characterization and Evaluation of a Quantum/Interband Cascade Laser Spectrometer for simultaneous airborne in situ observation of $\mathrm{CH}_{4}, \mathrm{C}_{2} \mathrm{H}_{6}, \mathrm{CO}_{2}, \mathrm{CO}$ and $\mathrm{N}_{2} \mathrm{O}$ " by

\title{
Julian Kostinek et al.
}

Julian Kostinek et al.

julian.kostinek@dlr.de

Received and published: 28 January 2019

The comment was uploaded in the form of a supplement:

https://www.atmos-meas-tech-discuss.net/amt-2018-312/amt-2018-312-AC3- 